Research Article

\title{
Exploring the Related Factors in Education Quality through Spatial Autoregressive Modeling with Latent Variables: A Rural Case Study
}

\author{
Anik Anekawati, ${ }^{1,2}$ Bambang W. Otok ${ }^{(D)},{ }^{2}$ Purhadi, ${ }^{2}$ and Sutikno ${ }^{2}$ \\ ${ }^{1}$ Faculty of Teacher Training and Education, Universitas Wiraraja, Sumenep 69451, Indonesia \\ ${ }^{2}$ Department of Statistics, Institut Teknologi Sepuluh Nopember, Surabaya 60111, Indonesia \\ Correspondence should be addressed to Bambang W. Otok; bambang_wo@statistika.its.ac.id
}

Received 30 June 2020; Accepted 18 September 2020; Published 7 October 2020

Academic Editor: Enrique Palou

Copyright (c) 2020 Anik Anekawati et al. This is an open access article distributed under the Creative Commons Attribution License, which permits unrestricted use, distribution, and reproduction in any medium, provided the original work is properly cited.

\begin{abstract}
The principle of education for sustainable development (ESD) is that no child is left behind. Hence, the fourth sustainable development goal (SDG) of the United Nations (UN) emphasizes inclusion and equity in education by focusing on eliminating disparities among regions. This study explores factors related to education quality through modeling in rural areas of Sumenep Regency, in East Java, Indonesia. Currently, only a few kinds of research studies involve spatial data, latent variables and, at the same time, tests of their spillover effects. The modeling herein is the spatial autoregressive model with latent variables (SAR-LVs). The latent variables were estimated using the weighted least square (WLS) method, while the Lagrange multiplier (LM) test was used for spatial dependence testing. The parameters of the SAR-LVs were estimated using two-stage least square (2SLS). The results show that the quality of education is directly influenced by the infrastructure of the schools but not by the socioeconomic conditions of the local communities. The autoregressive spatial coefficient has a significant but negative effect, which shows a negative spillover from districts with a lower quality of education to the ones with a high quality of education. This is due to the students' competition to get registered for a favorite or good quality school in a particular district, which stimulates the migration of students from its neighboring districts. This reveals the inequality of school quality, since not all students can get access to schools with good quality. Through this study, some recommendations are given as a contribution to achieving the fourth SDG in Indonesia.
\end{abstract}

\section{Introduction}

Indonesia is an archipelago with more than 16,000 islands that are $50.27 \%$ rural and $49.73 \%$ urban by area. It is also known as a multiethnic country with over 1,300 ethnicities divided into 31 ethnic groups [1]. The Indonesian Ministry of Education and Culture has identified 668 local languages in Indonesia, and its data show that $79.5 \%$ of the Indonesian population aged above five years communicates daily using local languages [1].

Based on its demographic and sociocultural characteristics, Indonesia has the potential to have a high disparity, particularly in education access and quality. Therefore,
Indonesia has tried to improve the educational attainment of children from low-income households in the context of equity in education for all. In 1997, the Indonesian government implemented a social safety net (SSN) program to buffer the hardship resulting from the economic crisis. The aim of the SSN program was to maintain the quality of the learning process and school enrollment rates and to reduce the dropout rates. The SSN program consists of scholarships for the poor and subsidies for the schools [2, 3]. In 2005, the Indonesian government implemented the school operational assistance (SOB) and an unconditional cash transfer program (UCT). The SOB program provided subsidies for both public and private schools with the aim of maintaining 
the quality of the educational service. UCT program was intended to anticipate the negative effects of the government's plan to reduce a fuel subsidy.

Kharisma [4] found that the provision of SOB had a positive effect on dropout rates for students aged between 16 and 20 years but not for those aged between 7 and 15 years. Furthermore, the Indonesian government has constantly committed to not leaving any child behind in development, as the core of the agenda 2030 on education for sustainable development (ESD). Since 2014, the Indonesian government has provided smart cards to more than 24 million poor students and others who cannot attend school because of financial issues. Based on the report [5], Indonesia is one of the low-income or middle-income countries whose share of the state budget for education is likely to be high. The amendment of the education budget was simultaneous with the start of a decentralized government system.

Since 1998, Indonesia has given greater autonomy to local governments due to the commencement of a reformation movement across Indonesia. Education management was also delegated more to the local governments. The constitution states that local governments are obliged to allocate a minimum of $20 \%$ of their budgets to the education sector. Furthermore, local governments have a crucial role in providing access to education.

Muttaqin [6] found that local governments with more resources can provide more scholarships to attract pupils from poor families to return to school, but this is not the case for local governments with fewer resources, such as local governments with greater rural areas. At least, there is a disparity in education quality between rural and urban areas and between western and eastern Indonesia. Based on welfare statistics [7], the percentage of the population who are aged above 15 years that literate is $97.49 \%$ in urban areas and $93.13 \%$ in rural areas. The school enrollment ratio of the population aged between 16 and 18 years is $75.21 \%$ in urban areas and $67.71 \%$ in rural areas. The net enrollment ratio of the population for senior high school is $64.33 \%$ in urban areas and $56.06 \%$ in rural areas. Azzizah [8] point out the apparent gap of education among the eastern and western provinces in Indonesia using the dummy regression analysis, and the most influencing factor was the poverty rate.

The report [9] showed that the Indonesian children and youth who do not have sufficient access to education are in remote and isolated areas and in poor communities. This report was based on data of the National Socioeconomic Survey 2015, which stated that the composition of the group of out-of-school children (OOSC) of elementary school age was $81 \%$ from rural areas (based on location), $49 \%$ from poor families (based on wealth), and $40 \%$ from Papua (based on region).

The fourth sustainable development goal (SDG) on education is to ensure inclusive and equitable education and to promote lifelong learning opportunities for all. One of the targets is "by 2030, to eliminate gender disparities in education and ensure equal access to all levels of education and vocational training for the vulnerable, including persons with disabilities, indigenous peoples, and children in vulnerable situations." One of the disparity indices is rural- urban. As reported in [10], youths aged between 20 and 24 years living in rural areas in 101 low- and middle-income countries have, on average, an education period 2.6 years shorter than do those in urban areas; Indonesia is one of these countries. In Indonesia, rural-urban disparities are widely prevalent across indicators in each target of the fourth SDG, since poverty is still concentrated in rural areas [9]. The report [5] shows that children born in selected rural areas in Indonesia who migrated to an urban area as children were found to have attained three more years of education than those who did not migrate. This shows that migration from rural to urban areas can increase educational attainment due to the low access to education in rural areas.

Therefore, some educational research studies have focused on rural areas to provide more specific reviews. Yue et al. [11] researched policy and trends in rural education from preschool to high school in China over 40 years, from 1978 to 2018. Rural schools continually improved in all aspects. In 1980, only a small proportion of rural children attended preschool, but in 2014, more than $90 \%$ of rural children attended preschool. Carrascal et al. [12] focused their research on rural primary schools in Mixco, Guatemala. They developed the E.CO Kit as an effective teaching-learning tool that contributed to improving the visual literacy and creativity of students. In Finland, digital communication is being more understandable by rural teachers than in the urban area and promoted parentteacher partnership in rural better than did parents in the urban area [13]. Cheng et al. [14] documented the learning problems of disadvantaged students in rural areas in Taiwan. The results showed that in rural elementary schools, the education levels of most of the parents were below the college level, students had low motivation, and the ordinary students and disadvantaged students indeed showed differences. Azzizah [8] found that poverty had a huge influence on the rate of school enrollment, particularly in Indonesia's eastern province, based on Joseph Nkurunziza's analysis (hindawi 2012) that students from very poor people have lower odds of attendance in school. Based on [9], poverty in Indonesia is still concentrated in rural areas.

East Java is one of the provinces in western Indonesia, and it is relatively more advanced than others. In East Java province, the OOSC rate in the primary school level is only $7 \%$, while in junior secondary, it is $12 \%$, and in senior secondary, it is $14 \%$. These numbers are relatively low compared to those in other provinces. However, one of the regencies in East Java has 100 underdeveloped regions, namely, Sumenep Regency [15]. The percentage of poor people in Sumenep Regency is $19.62 \%$, which is the fourth highest in East Java, and the human development index is 64.28, the fourth lowest in East Java [16].

The principle of ESD is that no child is left behind and emphasizes equity of education by focusing on eliminating disparities among regions and socioeconomic groups. Therefore, in this study, the factors related to education quality in Sumenep Regency were explored through the spatial autoregressive model with latent variables (SARLVs). Sumenep is a regency with rural characteristics. It is necessary to study the modeling of education quality, 
specifically rural cases, to get deeper and more specific information.

For this modeling, the SAR-LVs approach was used, since it involves spatial data and latent variables. Many studies on education have involved spatial data. Gille [17] tested the existence of education spillovers in a rural context in India using fixed-effects vector decomposition consisting of the three-stage estimation. The result was that one additional year of education of neighbors' increases farm productivity by $2 \%$. Gao et al. [18] analyzed the disparity in compulsory education based on the perspective of the imbalanced spatial distribution using spatial autocorrelation methods. Xu et al. [19] calculated the index of geographic accessibility, available opportunity, and economic affordability to describe the social spatial accessibility. In all these studies, spatial data were used, but the spillover effect was not tested. Therefore, the aim of the study herein was to perform modeling of education quality that involves spatial data and latent variables and to test the spillover effect. The case study takes Sumenep Regency, since Sumenep has the characteristics of an archipelago and multiethnic as a miniature of Indonesia but represents rural areas.

Sumenep Regency is one of the regencies in East Java Province, precisely at the eastern end of Madura Island. This region is located between $113^{\circ} 32^{\prime} 54^{\prime \prime}$ and $116^{\circ} 16^{\prime \prime} 48^{\prime \prime \prime}$ east longitude and $4^{\circ} 55^{\prime \prime} 00^{\prime \prime}$ and $7^{\circ} 24^{\prime \prime} 00^{\prime \prime}$ south latitude. The region borders Madura Straits to the south, the Java Sea to the north, Pamekasan Regency to the west, and the Java Sea and Flores Sea to the east. Geographically, Sumenep Regency consists of land and islands with a total area of $2,093.46 \mathrm{~km}^{2}$, namely, the mainland section of $1,146.93 \mathrm{~km}^{2}(54.79 \%)$ and the archipelago of $946.53 \mathrm{~km}^{2}$ (45.21\%). One hundred and twenty-six islands, consisting of 48 inhabited islands and 78 uninhabited islands, make up the archipelago, as shown in Figure 1.

Sumenep Regency is divided into 27 districts; 18 districts are on the mainland and 9 districts in the island. Districts on the mainland are Ambunten, Batang Batang, Batuan, Batuputih, Bluto, Dasuk, Dungkek, Ganding, Gapura, Guluk Guluk, Kalianget, Sumenep City, Lenteng, Manding, Pasongsongan, Pragaan, Rubaru, and Saronggi. Districts in the island are Arjasa, Gayam, Giligenteng, Kangayan, Masalembo, Nonggunong, Raas, Sapeken, and Talango. The population consists of at least six ethnic groups, namely, Madura, Bajo, Mandar, Bugis, Chinese, Arabic, and Javanese.

In 2018, the number of senior high schools in Sumenep Regency was 226, consisting of 13 public schools and 213 private schools. The number of private schools is far more than that of public schools, describing the community's independent participation in education. It is an interesting illustration if related to the level of poverty in the Sumenep Regency. Sumenep Regency has 334 villages, 100 of which were classified as disadvantaged villages [15]. Based on data [16], the percentage of poor people is 19.62 (the fourth highest in East Java), and the human development index is 64.28 (the fourth lowest in East Java).

\section{Materials and Methods}

2.1. Research Methods. This study focuses on the modeling of education quality at senior high schools using the SARLVs model. This modeling involves the latent variables, and the sample unit is location/spatial. Bollen [20] defined SEM in two models, namely, the measurement model and the structural model. The measurement model represents the relationship between the manifest variable and exogenous latent variables (1) or endogenous latent variables (2), while the structural model describes the relationship among the latent variables (3):

$$
\begin{aligned}
& \mathbf{x}=\boldsymbol{\Lambda}_{\mathbf{x}} \boldsymbol{\xi}+\boldsymbol{\delta}, \\
& \mathbf{y}=\boldsymbol{\Lambda}_{y} \boldsymbol{\eta}+\boldsymbol{\varepsilon}^{*}, \\
& \boldsymbol{\eta}=\mathbf{B}^{*} \boldsymbol{\eta}+\Gamma \xi+\zeta,
\end{aligned}
$$

where $\eta$ is a vector of an endogenous latent variable, $\xi$ is a vector of an latent variable, $\mathbf{B}^{*}$ is a coefficient matrix that shows the effect of an endogenous latent variable to another endogenous variables, $\Gamma$ is a coefficient matrix which shows the effect of $\xi$ to $\eta$, $\zeta$ is a vector of random error, $\mathbf{y}$ and $\mathbf{x}$ are the vectors of observed variable, $\Lambda_{\mathrm{y}}$ and $\Lambda_{x}$ are the coefficient matrices which show the relationship of $\mathbf{y}$ to $\eta$ and $\mathbf{x}$ to $\xi$, and $\varepsilon^{*}$ and $\delta$ are the vectors of measurements of $\mathbf{y}$ and $\mathbf{x}$, respectively, where $\varepsilon^{*} \sim \mathrm{N}_{\mathrm{B}}\left(0, \Theta_{\varepsilon^{*}}\right), \delta \sim \mathrm{N}_{\mathrm{A}}\left(0, \Theta_{\delta}\right)$, and $\Theta_{\delta}$ and $\Theta_{\varepsilon^{*}}$ are the covariant-variant matrices.

Anselin wrote the spatial autoregressive model (SAR) [21] as shown in equation (4):

$$
\mathbf{y}^{*}=\lambda \mathbf{W y}^{*}+\mathbf{X}^{*} \boldsymbol{\beta}+\boldsymbol{\varepsilon},
$$

where $\mathbf{y}^{*}$ is a vector of a spatially lagged dependent variable, $\mathbf{X}^{*}$ is a matrix of an exogenous variable, $\lambda$ is a spatial autoregressive coefficient, $\rho$ is a coefficient of a spatial error, $\beta$ is a vector of parameters associated with an exogenous variable, $\mathbf{W}$ is a matrix of spatial weight with the main diagonal elements being zero, and $\varepsilon$ is the disturbance with $\varepsilon \sim N\left(0, \sigma^{2} \mathbf{I}\right)$.

The factor score is the result of estimating the latent variables in the measurement model via equations (1) and (2) using the weighted least square (WLS) method. The factor scores for an endogenous variable and an exogenous random variable are given in equations (5) and (6), respectively:

$$
\begin{aligned}
& \widehat{\xi}^{\prime}=\left(\Lambda_{\mathbf{x}}^{\prime} \Theta_{\delta}^{-1} \Lambda_{\mathbf{x}}\right)^{-1}\left(\Lambda_{\mathbf{x}}^{\prime} \Theta_{\delta}^{-1}\right) \mathbf{X}, \\
& \widehat{\eta}^{\prime}=\left(\Lambda_{\mathbf{y}}^{\prime} \Theta_{\delta}^{-1} \Lambda_{\mathbf{y}}\right)^{-1} \Lambda_{\mathbf{y}}^{\prime} \Theta_{\delta^{*}}^{-1} \mathbf{Y},
\end{aligned}
$$

where $\mathbf{X}$ and $\mathbf{Y}$ are the random observation matrices.

The SAR-LVs model is obtained by replacing the spatially lagged dependent variable $\left(\mathbf{y}^{*}\right)$ and exogenous variable $\left(\mathbf{X}^{*}\right)$ in the spatial model of equation (4) with factor scores from equations (5) and (6). The dependent variable $\mathbf{y}^{*}$ is replaced by $\hat{\eta}$ and $\mathbf{X}^{*}$ is replaced by $\hat{\xi}$. Thus, the SAR-LVs model is written as shown in equation (7): 


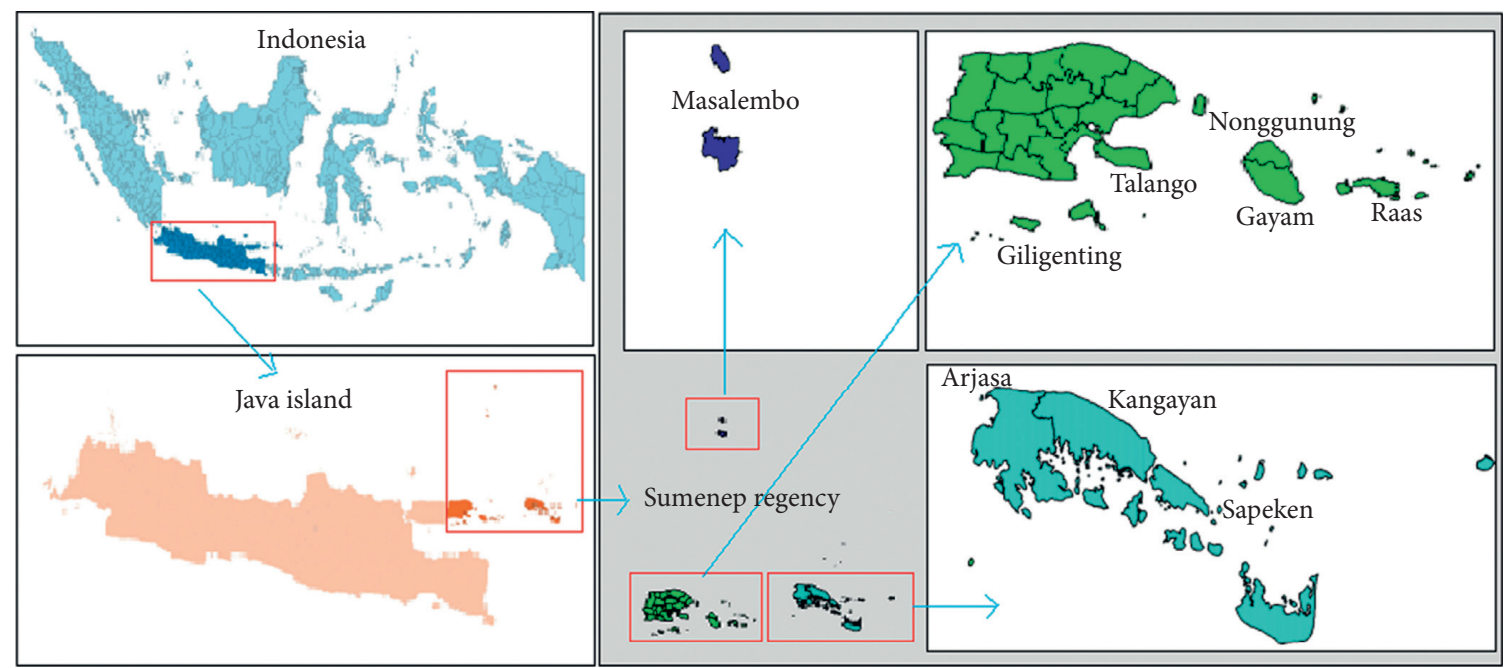

FIgURE 1: A map of the districts in Sumenep Regency.

$$
\widehat{\eta}=\lambda \mathbf{W} \widehat{\eta}+\widehat{\xi} \boldsymbol{\beta}+\boldsymbol{\varepsilon},
$$

where the error distribution of $\varepsilon$ is

$$
\boldsymbol{\varepsilon} \sim N_{T}\left((\mathbf{I}-\lambda \mathbf{W}) \mathbf{e} \widehat{\eta}_{t}-\widehat{\xi} \boldsymbol{\beta}, \boldsymbol{\Theta}\right),
$$

where $\quad \Theta=(\mathbf{I}-\lambda \mathbf{W})\left(\Lambda_{y}^{\prime} \Theta_{\delta}^{-1} \Lambda_{y}\right)^{-1}(\mathbf{I}-\lambda \mathbf{W}), \quad$ and $\mathbf{e}=(1, \ldots, 1)^{\prime}$.

Anselin [22] developed diagnostics for spatial dependence using the Lagrange multiplier (LM) test. The LM approach seems reasonable and relatively easy based on estimation under the null hypothesis [23], i.e., in its most simple form. The spatial dependence test of the SAR-LVs model, as shown in equation (7), makes use of the LM test developed by Anselin [22] but based on the error distribution as shown in equation (8). The value of the test statistic LM SAR-LVs is

$$
\mathrm{LM}_{\lambda}=\frac{-\left(p(\mathbf{W} \hat{\xi} \boldsymbol{\beta})^{\prime} \widetilde{\varepsilon}\right)^{2}}{p D}
$$

where $p=\left(\Lambda_{y}^{\prime} \Theta_{\delta}^{-1} \Lambda_{y}\right), D=\left(\mathbf{e} \widehat{\eta}_{t}-\widehat{\xi} \beta\right)^{\prime} \mathbf{W} W^{\prime}\left(\mathbf{e} \widehat{\eta}_{t}-\widehat{\xi} \beta\right), \widetilde{\varepsilon}=$ $(\widehat{\eta}-\widehat{\xi} \beta)$, and $\mathbf{e}=(1, \ldots, 1)^{\prime}$.

The parameters of SAR-LVs in equation (7) are estimated using the using the two-stage least square (2SLS) method, reviewed by $[24,25]$.

The SAR-LVs model as shown in equation (7) can be simplified as follows: $\widehat{\eta}=\mathbf{Z} \alpha+\varepsilon$, where $\mathbf{Z}=(\widehat{\xi} \mid \mathbf{W} \widehat{\eta})$, and $\alpha=\left(\beta^{\prime} \mid \lambda\right)^{\prime}$. The 2SLS method requires an instrument variable, which is a joint of the $\widehat{\xi}$ matrix and the $\mathbf{W} \widehat{\xi}$ matrix or written as $\mathbf{H}=(\widehat{\xi} \mid \mathbf{W} \widehat{\xi})$. The instrument variable $\mathbf{H}$ is valid because it does not correlate with $\boldsymbol{\varepsilon}$ but correlates with regressor $\mathbf{W} \hat{\eta}$. The result of the estimation is

$$
\widehat{\alpha}=\left(\widehat{Z}^{\prime} \widehat{Z}\right)^{-1} \widehat{Z}^{\prime} \hat{\eta},
$$

where $\widehat{Z}=\mathbf{H}\left(H^{\prime} \mathbf{H}\right)^{-1} H^{\prime} \mathbf{Z}$ and $\widehat{\alpha}$ contains $\widehat{\beta}$ and $\widehat{\lambda}$.

The parameter significance test using the maximum likelihood ratio test (MLRT) method and based on the error distribution as in (8) is

$$
c=\left(\Lambda^{-2 / n}-1\right)(n-1),
$$

where $\Lambda^{-2 / n}=1+(n /(n+1))(\widehat{\xi} \widehat{\beta})^{\prime}\left(\Lambda_{y}^{\prime} \Theta_{\delta}^{-1} \Lambda_{y}\right) \mathbf{I}_{T}(\widehat{\xi} \widehat{\beta})^{\prime}$. The materials and methods section should contain sufficient detail so that all procedures can be repeated. It may be divided into headed subsections if several methods are described.

2.2. Indicator, Latent Variable, Model, and Unit Sample. This study models the quality of education at senior high schools in Sumenep Regency, Indonesia. This modeling involves two exogenous latent variables and one endogenous latent variable. The exogenous latent variables are school infrastructure and the socioeconomic condition, whereas the endogenous latent variable is education quality.

Indicators for the variables of education quality were constructed based on the study by Kemendikbud [26]. Regulation in the study by Kemendiknas [27] was used to determine the indicators for the variable of school infrastructure. The indicators for each variable are shown in Table 1. Indicators are secondary data in Sumenep Figure 2018 [16] and data from education office Sumenep Regency 2018.

The conceptual model was constructed of three latent variables, namely, the education quality influenced by the socioeconomic conditions of the community [26] and by infrastructure facilities [28]. The theoretical hypothetical model was based on the conceptual model, as shown in Figure 2.

The observation units in this study are districts in Sumenep Regency. There are 27 districts, consisting of 18 districts on the mainland and 9 districts on islands. There are 226 senior high schools, consisting of 12 public schools, 1 public madrasa (Islamic school) school, 72 private nonmadrasa schools, and 141 private madrasa schools. Table 2 is a number and kind of senior high school in each district. 
TABLE 1: Latent variables and their indicators.

\begin{tabular}{|c|c|c|}
\hline Latent variable & Indicator & Brief description \\
\hline \multirow{3}{*}{ Education quality } & $Y_{11}$ & $\begin{array}{l}\text { The ratio of the gross enrolled number of senior high school students to the number of children aged } \\
\text { between } 15 \text { and } 18 \text { years in each district. }\end{array}$ \\
\hline & $Y_{12}$ & $\begin{array}{l}\text { The ratio of the number of accredited senior high schools with at least B level to the total number of } \\
\text { senior high schools in each district. }\end{array}$ \\
\hline & $Y_{13}$ & The average of national exam scores of senior high school students in each district. \\
\hline \multirow{3}{*}{ School infrastructure } & $X_{11}$ & $\begin{array}{c}\text { The proportion of the number of schools having minimum classroom space according to the } \\
\text { regulations of the national education ministry. }\end{array}$ \\
\hline & $X_{12}$ & $\begin{array}{l}\text { The proportion of the number of schools having laboratories according to the regulations of the } \\
\text { national education ministry. }\end{array}$ \\
\hline & $X_{13}$ & $\begin{array}{c}\text { The proportion of the number of schools having libraries according to the regulations of the national } \\
\text { education ministry. }\end{array}$ \\
\hline \multirow{2}{*}{$\begin{array}{l}\text { Socioeconomic } \\
\text { conditions }\end{array}$} & $X_{21}$ & $\begin{array}{l}\text { The ratio of the number of households running a home industry or having a shop at home to the total } \\
\text { number of households in each district. }\end{array}$ \\
\hline & $X_{22}$ & $\begin{array}{c}\text { The ratio of the number of households using clean water to the total number of households in each } \\
\text { district. }\end{array}$ \\
\hline
\end{tabular}

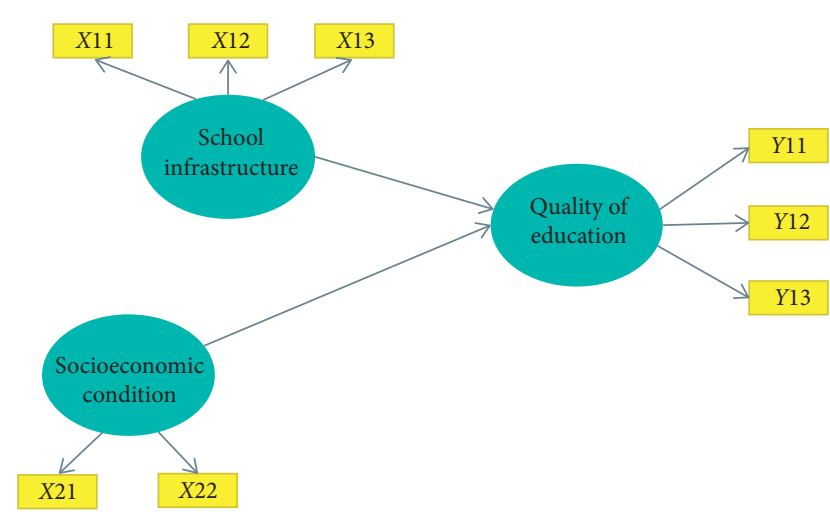

FIgURE 2: Theoretical hypothetical model of quality of education at senior high schools.

\subsection{The Parameter Estimation Step and Significance Test}

2.3.1. Evaluating the Measurement Model. Evaluation of the measurement model is conducted to ensure that indicators are constructing their latent variables properly. This work used smart-PLS.

2.3.2. Estimating the Latent Variable. Factor scores were obtained based on equations (5) and (6) and calculated using a MATLAB program.

2.3.3. Setting the Spatial Weights. The spatial weighting used the Queen contiguity method. In Queen contiguity, $\mathrm{W}_{\mathrm{ij}}$ is defined as 1 for an entity where the common side or the common vertex meets the region of concern, and $\mathrm{W}_{\mathrm{ij}}$ is defined as 0 for other regions [29].

2.3.4. Modeling the SAR-LVs. The model was constructed based on equation (7) with one endogenous variable, two exogenous variables, and 27 observation units; the SAR-LVs model can be rewritten as $\widehat{\widetilde{\eta}}_{i}=\widehat{b}_{0}+\hat{\lambda} \sum_{j=1, i \neq j}^{27} W_{i j} \widehat{\eta}_{j}+\widehat{b}_{1} \widehat{\xi}_{1}+\widehat{b}_{2} \widehat{\xi}_{2}$.
2.3.5. Testing the Spatial Dependency. The value of the test statistic LM SAR-LVs is as given in equation (9) and was calculated using a MATLAB program. The LM statistic $L M_{\lambda}$ follows the asymptotic distribution of $X_{(1)}^{2}$.

2.3.6. Estimating the Parameters. The parameters of the SAR-LVs model were obtained based on equation (10) and calculated using a MATLAB program.

2.3.7. Testing the Statistical Significance. The value of the parameter significance test is as given in equation (11) and was calculated using a MATLAB program. The statistic of $c$ follows the asymptotic distribution of $F_{1(n-1)}$. If $c>F_{1(n-1)}$, then it has a spatial effect.

2.4. Theoretical Hypothesis. A hypothetical model was proposed as shown in Figure 2 that shows the path hypotheses in which socioeconomic conditions and school infrastructure directly affect the quality of education. The spatial effect is to be tested since observation units are locations. Furthermore, the following hypotheses were proposed:

Hypothesis H1: there is a spatial effect.

Hypothesis H2: school infrastructure has direct effects on the quality of education.

Hypothesis H3: socioeconomic conditions have direct effects on the quality of education.

\section{Results and Discussion}

3.1. Results. The review of the measurement model was based on convergent validity, composite reliability, and the significance test. Convergent validity was measured by the loading factors that are the coefficients of correlation between the indicators and their latent constructs. Indicators that have high loading factors contribute to explaining latent constructs more. Table 3 shows the loading factor value of each indicator. 
TABLE 2: Number and kind of school in each district.

\begin{tabular}{|c|c|c|c|}
\hline Code & Districts & Number of school & Explanation \\
\hline 010 & Pragaan & 26 & 4 private nonmadrasa and 22 private madrasa \\
\hline 020 & Bluto & 14 & 1 public, 1 private nonmadrasa, and 12 private madrasa \\
\hline 030 & Saronggi & 3 & 3 private madrasa \\
\hline 040 & Giligenteng & 6 & 1 private nonmadrasa and 5 private madrasa \\
\hline 050 & Talango & 1 & 1 private nonmadrasa \\
\hline 060 & Kalianget & 1 & 1 public \\
\hline 070 & Kotasumenep & 14 & 2 publics, 7 private nonmadrasa, 1 public madrasa, and 4 private madrasa \\
\hline 071 & Batuan & 2 & 1 public and 1 private nonmadrasa \\
\hline 080 & Lenteng & 19 & 1 public, 4 private nonmadrasa, and 14 private madrasa \\
\hline 090 & Ganding & 18 & 6 private nonmadrasa and 12 private madrasa \\
\hline 100 & Guluk Guluk & 21 & 8 private nonmadrasa and 13 private madrasa \\
\hline 110 & Pasongsongan & 6 & 1 private nonmadrasa and 5 private madrasa \\
\hline 120 & Ambunten & 6 & 1 public, 2 private nonmadrasa, and 3 private madrasa \\
\hline 130 & Rubaru & 9 & 2 private nonmadrasa and 7 private madrasa \\
\hline 140 & Dasuk & 5 & 1 private nonmadrasa and 4 private madrasa \\
\hline 150 & Manding & 4 & 2 private nonmadrasa and 2 private madrasa \\
\hline 160 & Batuputih & 2 & 1 private nonmadrasa and 1 private madrasa \\
\hline 170 & Gapura & 8 & 1 public, 2 private nonmadrasa, and 5 private madrasa \\
\hline 180 & Batang Batang & 8 & 4 private nonmadrasa and 4 private madrasa \\
\hline 190 & Dungkek & 5 & 3 private nonmadrasa and 2 private madrasa \\
\hline 200 & Nonggunong & 2 & 2 private nonmadrasa \\
\hline 210 & Gayam & 3 & 1 public, 1 private nonmadrasa, and 1 private madrasa \\
\hline 220 & Raas & 5 & 3 private nonmadrasa and 2 private madrasa \\
\hline 230 & Sapeken & 18 & 1 public, 5 private nonmadrasa, and 12 private madrasa \\
\hline 240 & Arjasa & 6 & 1 public, 4 private nonmadrasa, and 1 private madrasa \\
\hline 241 & Kangayan & 8 & 4 private nonmadrasa and 4 private madrasa \\
\hline 250 & Masalembu & 6 & 1 public, 2 private nonmadrasa, and 3 private madrasa \\
\hline
\end{tabular}

TABLE 3: The value of the loading factor.

\begin{tabular}{|c|c|c|c|c|c|}
\hline \multicolumn{2}{|c|}{ Quality of education } & \multicolumn{2}{|c|}{ School infrastructure } & \multicolumn{2}{|c|}{ Socioeconomic condition } \\
\hline Indicator & Loading factor & Indicator & Loading factor & Indicator & Loading factor \\
\hline$Y 11$ & 0.725 & $X 11$ & 0.890 & $X 21$ & 0.444 \\
\hline$Y 12$ & 0.844 & $X 12$ & 0.702 & $X 22$ & 0.910 \\
\hline$Y 13$ & 0.574 & $X 13$ & 0.685 & & \\
\hline
\end{tabular}

Some references stated that a factor loading of 0.50 was considered to have sufficient validation to explain the latent variable [30]. Sharma [31] mentioned that researchers had used cutoff values of factor loading as low as 0.40 . All indicators in Table 3 are more than 0.40 , so it is said to be sufficient to explain all the latent variables of education quality, school infrastructure, and socioeconomic condition.

Reliability testing was carried out to prove the accuracy and consistency of instruments in measuring latent variables. In this study, the reliability was tested/assessed using composite reliability. Generally, the composite reliability value of greater than 0.6 is acceptable [32]. Table 4 summarizes the results of the composite reliability test of three latent variables.

As shown in Table 4, all the composite reliability values of each latent variable are more than 0.6. It indicates that all latent variables are reliable, or indicators are consistent in measuring each of the latent variables.

In the SEM PLS method, the significance of the model cannot be tested because the data distribution is unknown. Therefore, the bootstrapping resampling method was used to conduct the significance test. Table 5 shows a summary of the significance test results for the measurement model with $\alpha=10 \%$.

As can be seen from the previous table, the only invalid indicator is $X 21$, representing the ratio of the number of households running a home industry or having a shop at home to the total number of households. However, in general, these indicators can still be used to construct latent variables.

The result of the identification of the spatial effect on the model of the education led to the SAR-LVs model at the significance level $\alpha=5 \%$. The results of the parameters estimation and significance test are summarized in Table 6.

In general, the SAR-LVs model for the education quality of the senior high school is $\widehat{\widetilde{\eta}}_{i}=9.6604-0.002 \sum_{j=1, i \neq j}^{27} W_{i j} \widehat{\eta}_{j}+2.3121 \widehat{\xi}_{1}+0.1286 \widehat{\xi}_{2}$, where $\hat{\eta}_{i}$ is the quality of education in $i^{\text {th }}$ district, $\widehat{\xi}_{1}$ is the infrastructure, and $\widehat{\xi}_{2}$ is the socioeconomic condition.

Models of the education quality of the senior high schools in the SAR-LVs model for several districts are as follows: 
TABle 4: Composite reliability.

\begin{tabular}{lc}
\hline Latent variable & Composite reliability \\
\hline Quality of education & 0.762 \\
School infrastructure & 0.806 \\
Socioeconomic condition & 0.653 \\
\hline
\end{tabular}

(1) Masalembo with no one neighboring district: $\widehat{\tilde{\eta}}_{(250)}=9.6604+2.3121 \widehat{\xi}_{1}+0.1286 \widehat{\xi}_{2}$.

(2) Nonggunong with one neighboring district: $\widehat{\widehat{\eta}}_{(200)}=9.6604-0.002 \widehat{\eta}_{(210)}+2.3121 \widehat{\xi}_{1}+0.1286 \widehat{\xi}_{2}$.

(3) Saronggi with five neighboring districts: $\widehat{\tilde{\eta}}_{(030)}=$ $9.6604-0.0004 \widehat{\eta}_{(020)}-0.0004 \widehat{\eta}_{(080)}-0.0 .0004 \widehat{\eta}_{(060)}$ $-0.0 .0004 \widehat{\eta}_{(070)}-0.0 .0004 \widehat{\eta}_{(071)}+2.3121 \widehat{\xi}_{1}+0.1286 \widehat{\xi}_{2}$.

(4) Sumenep City with six neighboring districts:

$$
\begin{aligned}
\widehat{\widetilde{\eta}}_{(070)}= & 9.6604-0.0003 \widehat{\eta}_{(030)} \\
& -0.0003 \widehat{\eta}_{(130)}-0.0003 \widehat{\eta}_{(060)} \\
& -0.0003 \widehat{\eta}_{(150)}-0.0003 \widehat{\eta}_{(071)} \\
& +2.3121 \widehat{\xi}_{1}+0.1286 \widehat{\xi}_{2} .
\end{aligned}
$$

3.2. Discussion. There are three items to be discussed, namely, the spatial effect and the influence of the school infrastructure and socioeconomic conditions on the quality of education. The autoregressive spatial coefficient significantly effects at the $5 \%$ significance level. This means that there is a correlation between the education quality of the senior high schools in one district and the one in other contiguous districts. However, the autoregressive spatial coefficient is negative. It indicates the opposite of the common spillover effect, i.e., the districts with a higher education quality are supported by or gains a spillover effect from the neighboring districts with lower education quality. The opposite of the spillover effect can be illustrated as the phenomenon "there is sugar, so there are ants," i.e., there are migrations of good students to districts with a higher number of high-quality schools.

The following social phenomenon can explain this situation. There is a tendency among Indonesian people to send their children to their favorite schools to ensure a good quality education, even though the schools are located far from their home. In urban areas, there are many favorite schools-not only public schools but even many private schools that are preferred by the community because of their good quality. In rural areas, particularly Sumenep Regency, the favorite schools are mostly public schools. Districts that have many favorite schools tend to have many applicants or prospective students, and they select the best students, including the ones from neighboring districts. Consequently, schools of good quality tend to be in demand by the community, even in other districts, especially the directly neighboring districts. On the contrary, schools in the directly neighboring districts lose good students from their own district or gain students of poorer quality from other districts since the quality of new students is one of the determinants of education quality. As a result of this phenomenon, districts are classified into two categories, namely receiving and losing districts. The receiving districts are districts whose number of new students of senior high school is more than the number of junior high school graduates in the same year. On the opposite, the losing districts are the ones that lose junior high school graduates. Figure 3 shows both district categories, including the directions of the student migration. This figure is created using the number of new students of senior high school and the number of junior high school graduates in Sumenep Regency in 2018 according to the Central Bureau of Statistics (BPS) [16].

Examples for receiving and losing districts are Sumenep City (Kotasumenep) and Saronggi, respectively (Figure 3). Based on the BPS data [16], the number of junior high school graduates in Sumenep City was 1,582, and the number of new students of senior high school was 2,041. It means that Sumenep City received students for the high school level from its neighboring districts. Referring to (12), there is a negative spillover in terms of good students input to Sumenep City from its neighboring districts, namely Saronggi, Rubaru, Kalianget, Manding, Batuan, and Gapura. Sumenep City has three public senior high schools that are strongly favored by the community or by students, while its three neighboring districts, Saronggi, Rubaru, and Manding, do not have any public schools. The other neighboring districts, Kalianget, Batuan, and Gapura, have only one public school. This condition stimulates the migration of students who have graduated from junior high school in the neighboring districts to register for senior high schools in Sumenep City. In other words, the high schools in Sumenep City always have the privilege of choosing the best students. In general, the favorite public schools in Sumenep regency are dominated by people of a good economic level who could support improvements in the quality of schools.

As an example of the losing districts, Saronggi has no public school and has five neighboring districts. Based on data [16], Saronggi had 305 junior high school graduates and 71 new senior high school students in 2018. It lost senior high school students due to migration to the neighboring districts, all of which have favorite public schools (Figure 3). The remaining 71 new senior high school students registered for three private madrasa schools in Saronggi.

The students' migration in Sumenep City and Saronggi districts show that students compete to get registered for favorite or good quality schools. It also reveals the inequality of the school quality, since not all students can have access to schools with a good quality. The urbanization correlated with gender equality in education because the urban population is generally also more receptive to modern views on female education for 57 developing countries in 1970-2010 [33]. To eliminate school favoritism, the Indonesian government issued a zoning system policy through the Minister of Education and Culture Regulation No. 17 of 2017, No. 14 of 2018, and No. 51 of 2018. The Ministry argues that student admission via the zoning system will improve access to education services in public schools for all and remove favorite schools as a basis for school selection. However, the zoning system policy is only for public schools. 
TABLE 5: The significance test results.

\begin{tabular}{|c|c|c|c|c|c|c|c|c|}
\hline \multicolumn{3}{|c|}{ Quality of education } & \multicolumn{3}{|c|}{ School infrastructure } & \multicolumn{3}{|c|}{ Socioeconomic condition } \\
\hline Indicator & $T$ value & Interpretation & Indicator & $T$ value & Interpretation & Indicator & $T$ value & Interpretation \\
\hline$Y 11$ & 2.849 & Valid & $X 11$ & 9.427 & Valid & $X 21$ & 1.322 & Nonvalid \\
\hline$Y 12$ & 4.061 & Valid & $X 12$ & 4.183 & Valid & $X 22$ & 3.616 & Valid \\
\hline$Y 13$ & 2.045 & Valid & $X 13$ & 1.904 & Valid & & & \\
\hline
\end{tabular}

TABLE 6: The estimation results of the parameters.

\begin{tabular}{lccc}
\hline Variable & Coefficient & Significance test & Hypothesis \\
\hline Spatial autoregressive coefficient $(\lambda)$ & -0.002 & Significant & H1 \\
School infrastructure $(b 1)$ & 2.3121 & Significant & H2 \\
Socioeconomic condition $(b 2)$ & 0.1286 & Not significant & H3 \\
Constant $(b 0)$ & 9.6604 & Significant & - \\
\hline
\end{tabular}

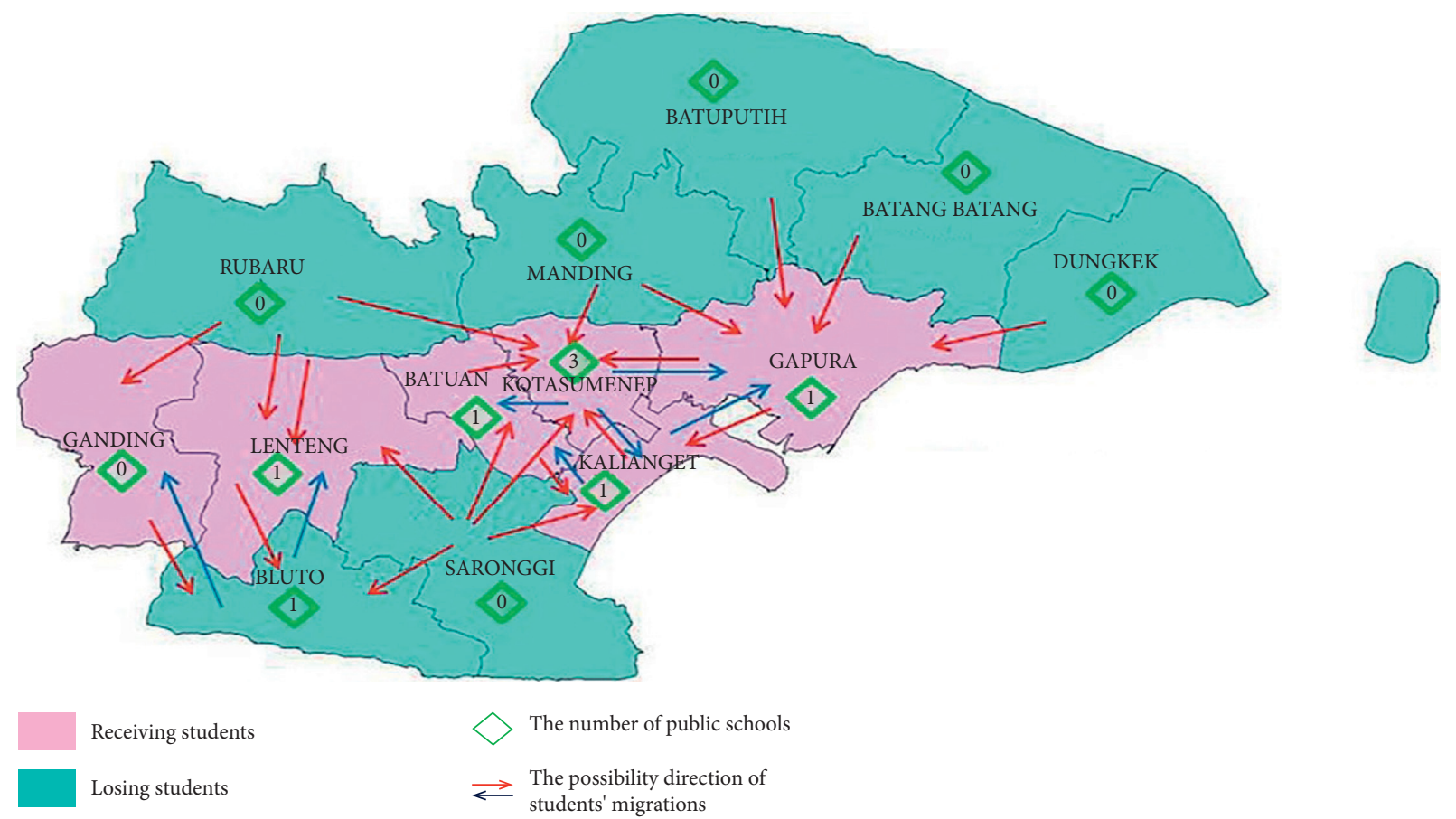

Figure 3: The receiving and losing districts and the directions of the students' migration.

Sumenep Regency implemented a zoning system policy starting in the middle of 2018. Sumenep has only 13 public senior high schools out of a total of 226 senior high schools, which are spread across 11 districts. These 13 public senior high schools are not enough to accommodate all senior high school students in Sumenep. As a result, many private schools have emerged as community initiations. Thus, private schools play an important role in bridging the gap and providing access to education in rural areas. However, private schools are generally inferior in terms of education quality and facilities [34]. As many as $67.7 \%$ of private schools in Sumenep Regency has a C accreditation or not even accredited. The standardization of private and public schools is very important in order to obtain uniform quality among schools, especially when this zoning system is applied. If a public school is unable to accommodate students in a district, then a private school with almost the same quality will be able to accommodate them.

The result of this modeling describes the influence of the school infrastructure variable as follows: each level of school infrastructure improvement is followed by an increase of 2.3121 in the quality of education in a district. This means that indicators of the school infrastructure variable based on regulations by the Ministry of National Education are positively correlated to indicators of the education quality variable based on the strategic planning of education for 2015-2019. This finding is supported by the research by Bedi and Garg [35] where the effectiveness of private versus public schools in Indonesia based on labor market earnings was studied. Schools were classified into four different types, namely, public, private nonreligious, private Islamic, and private Christian schools. One of the results revealed that 
students of schools with poor infrastructure earned between $25 \%$ and $57 \%$ (for public and private nonreligious schools) less than those of schools with adequate infrastructure. The school infrastructure in Sumenep Regency directly influences the quality of education. It becomes an important part to be prepared carefully and continuously by the local government so that the ESD can be achieved.

Socioeconomic condition was found to not have a significant impact on the quality of education. Azziza [8] revealed that socioeconomic inequality caused educational disparities in eastern and western Indonesia, but the research did not explain the actual situation in the regions. In Sumenep Regency, the number of private schools has reached $94.25 \%$ of the total (213 of 226 schools); of all schools there, $5.31 \%$ is public, $0.44 \%$ is public madrasa schools, $31.86 \%$ is private nonmadrasa schools, and $62.39 \%$ is private madrasa schools. Private schools, as a representation of the community's independent participation in educational services, reflect the community's socioeconomic condition. Meanwhile, based on statistical data [36], economic growth and the gross regional domestic product (GRDP) per capita in Sumenep are below the average economic growth and GRDP of regencies in East Java. Sari [34] argued that, in general, private schools are inferior in terms of quality and facilities. A large number of private schools in the Sumenep regency do not reflect yet the socioeconomic condition of the local community. They still rely on the SOB fund. Nurkholis [37] suggested that the quality of madrasa schools was still low when compared with other schools for the same education level. In Sumenep, the majority of senior high schools are private madrasa schools. These schools were built by the community to poor quality standards since religious idealism was prioritized. Therefore, in this model, the socioeconomic variable has no effect to the quality of education.

\section{Conclusions}

The main conclusions of this study are as follows: (1) there is a negative spillover effect due to the migration of good students from districts to the others with higher education quality, (2) the school infrastructure directly influences the quality of education, and (3) socioeconomic conditions do not have a significant impact on the quality of education. This study recommends that it is necessary to standardize the quality of all schools, especially private schools in Sumenep Regency, so that the zoning system can function well. In the standardization process, the role of the central government is crucial. The central government should provide guidance or assistance to the local governments in achieving the desired outcomes when implementing the zoning system, such as by accelerating the provision of teachers, facilities, and infrastructure. Furthermore, the education quality of rural private schools needs to be improved since this also means providing better education for children from low-income families to achieve equality of access and quality of education for all children. In that way, ESD can be carried out properly. Research for specific regions (e.g., in this case, Sumenep Regency) should be conducted to obtain more specific information about the problems that are present and certainly distinct from those in other regions. The study of specific cases can be used as a benchmark for making policy. Each policy thus made provides solutions that are relevant to regional problems and capabilities.

\section{Data Availability}

The data used to support the findings of this study are available from the corresponding author upon request.

\section{Conflicts of Interest}

The authors declare that there are no conflicts of interest regarding the publication of this paper.

\section{References}

[1] B. P. S. Kewarganegaraan, Suku Bangsa, Agama, Dan Bahasa Sehari-Hari Penduduk Indonesia: Hasil Sensus Penduduk 2010, Badan Pusat Statistik, Jakarta, Indonesia, 2011.

[2] S. Sumarto, A. Suryahadi, and W. Widyanti, "Designs and implementation of Indonesian social safety net programs," The Developing Economies, vol. 40, no. 1, pp. 3-31, 2002.

[3] R. Sparrow, "Protecting education for the poor in times of crisis: an evaluation of a scholarship programme in Indonesia," Oxford Bulletin of Economics and Statistics, vol. 69, no. 1, pp. 99-122, 2007.

[4] B. Kharisma, "Dampak program bantuan operasional sekolah (BOS) terhadap tingkat putus sekolah di Indonesia: analisis DID," Jurnal Ekonomi Kuantitatif Terapan, vol. 6, p. 10, 2013.

[5] UNESCO, Global Education Monitoring Report Summary 2019: Migration, Displacement and Education-Building Bridges, Not Walls, United Nations Educational, Scientific and Cultural Organization, Paris, France, 2018.

[6] T. Muttaqin, "Determinants of unequal access to and quality of education in Indonesia," Jurnal Perencanaan Pembangunan: The Indonesian Journal of Development Planning, vol. 2, no. 1, 2018.

[7] BPS, BPS Welfare Statistics 2019, BPS-Statistics Indonesia, Jakarta, Indonesia, 2019.

[8] Y. Azzizah, "Socio-economic factors on Indonesia education disparity," International Education Studies, vol. 8, no. 12, p. 218, 2015.

[9] KEMDIKBUD, UNICEF. SDG4 Baseline Report for Indonesia, Indonesia Ministry of Education and Culture and the United Nations Children's Fund (UNICEF), Jakarta, Indonesia, 2017.

[10] UNESCO, Global Education Monitoring Report Summary 2016, Education for People and Planet: Creating Sustainable Futures for All, United Nations Educational, Scientific and Cultural Organization, Paris, France, 2016.

[11] A. Yue, B. Tang, Y. Shi et al., "Rural education across China's 40 years of reform: past successes and future challenges," China Agricultural Economic Review, vol. 10, no. 1, pp. 93118, 2018.

[12] S. Carrascal, M. Magro, J. Anguita, and M. Espada, "Acquisition of competences for sustainable development through visual thinking. A study in rural schools in Mixco, Guatemala," Sustainability, vol. 11, no. 8, p. 2317, 2019.

[13] A.-M. Kuusimäki, L. Uusitalo-Malmivaara, and K. Tirri, "Parents' and teachers' views on digital communication in 
Finland," Education Research International, vol. 2019, Article ID 8236786, 7 pages, 2019.

[14] C.-H. Cheng, Y.-C. Wang, and W.-X. Liu, "Exploring the related factors in students' academic achievement for the sustainable education of rural areas," Sustainability, vol. 11, no. 21, p. 5974, 2019.

[15] P. P. M. D. Dirjen, Keputusan Direktur Jenderal Pembangunan Dan Pemberdayaan Masyarakat Desa Nomor 201 Tahun 2019, Tentang Perubahan Kedua Atas Keputusan Dirjen Pembangunan Dan Pemberdayaan Masyarakat Desa Nomor 30 Tahun 2016 Tentang Status Kemajuan Dan Kemandirian Desa, 2019.

[16] BPS Sumenep in Figures 2018; BPS-Statistics of Sumenep Regency: Sumenep, 2018.

[17] V. Gille, "Education spillovers: empirical evidence in rural India," Indian Growth and Development Review, vol. 5, no. 1, pp. 4-24, 2012.

[18] Y. Gao, Q. He, Y. Liu, L. Zhang, H. Wang, and E. Cai, "Imbalance in spatial accessibility to primary and secondary schools in China: guidance for education sustainability," Sustainability, vol. 8, no. 12, p. 1236, 2016.

[19] Y. Xu, W. Song, and C. Liu, "Social-spatial accessibility to urban educational resources under the school district system: a case study of public primary schools in Nanjing, China," Sustainability, vol. 10, no. 7, p. 2305, 2018.

[20] K. A. Bollen, Structural Equations with Latent Variables, John Wiley \& Sons, New York, NY, USA, 1989.

[21] L. Anselin, Spatial Econometrics: Methods and Models, Vol. 4, Kluwer Academic Publisher, Dordrecht, Netherlands, 1988.

[22] L. Anselin, "Lagrange multiplier test diagnostics for spatial dependence and spatial heterogeneity," Geographical Analysis, vol. 20, no. 1, pp. 1-17, 1988.

[23] T. S. Breusch and A. R. Pagan, "The Lagrange multiplier test and its applications to model specification in econometrics," The Review of Economic Studies, vol. 47, no. 1, pp. 239-253, 1980.

[24] H. H. Kelejian and I. R. Prucha, "A generalized spatial twostage least squares procedure for estimating a spatial autoregressive model with autoregressive disturbances," The Journal of Real Estate Finance and Economics, vol. 17, no. 1, pp. 99-121, 1998.

[25] H. H. Kelejian and I. R. Prucha, "A generalized moments estimator for the autoregressive parameter in a spatial model," International Economic Review, vol. 40, no. 2, pp. 509-533, 1999.

[26] Kemendikbud, Rencana Strategis Kementerian Pendidikan Dan Kebudayaan Tahun 2015-2019, 2015.

[27] Kemendiknas, Peraturan Menteri Pendidikan Nasional Nomor 24 Tahun 2007, 2007.

[28] P. Barrett, A. Treves, T. Shmis, D. Ambasz, and M. Ustinova, The Impact of School Infrastructure on Learning: A Synthesis of the Evidence, The World Bank, Washington, DC, USA, 2019.

[29] J. P. LeSage, The Theory and Practice of Spatial Econometrics, Department of Economics University of Toledo, Toledo, $\mathrm{OH}$, USA, 1999.

[30] J. F. Hair, W. C. Black, and B. J. Babin, Multivariate Data Analysis, Prentice-Hall, Upper Saddle River, NJ, USA, 7th edition, 2009.

[31] S. Sharma, Applied Multivariate Techniques, John Wiley \& Son Inc, New York, NY, USA, 1st edition, 1996.

[32] K. S. Sujit and B. K. Rajesh, "Determinants of discretionary investments," SAGE Open, vol. 6, no. 1, 2016.

[33] G. Østby, H. Urdal, and I. Rudolfsen, "What is driving gender equality in secondary education? Evidence from 57 developing countries, 1970-2010," Education Research International, vol. 2016, Article ID 4587194, 18 pages, 2016.

[34] V. A. Sari, "Educational assistance and education quality in Indonesia: the role of decentralization," Population and Development Review, vol. 45, no. S1, pp. 123-154, 2019.

[35] A. S. Bedi and A. Garg, "The effectiveness of private versus public schools: the case of Indonesia," Journal of Development Economics, vol. 61, no. 2, pp. 463-494, 2000.

[36] BPS Produk, Domestik Regional Bruto Kabupaten/Kota Di Provinsi Jawa Timur Menurut Lapangan Usaha 2014-2018, BPS Provinsi Jawa Timur, Surabaya, Indonesia, 2019.

[37] N. Nurkolis, "Educational improvement towards effective madrasah," in Proceedings of the 1st Yogyakarta International Conference on Educational Management/Administration and Pedagogy (YICEMAP 2017), Atlantis Press, Yogyakarta, Indonesia, 2017. 